\title{
ORGANIZATIONAL AND LEGAL BASIS OF COOPERATION OF UKRAINE AND THE EUROPEAN UNION IN THE LAW ENFORCEMENT FIELD ORGANIZATIONAL AND LEGAL BASIS OF COOPERATION OF UKRAINE AND THE EUROPEAN UNION IN THE LAW ENFORCEMENT FIELD
}

\section{Bondar V. V.}

\section{INTRODUCTION}

In connection with Ukraine's determination of a strategic goal integration into the European Union, including membership in this international association - it is an important task to bring national legislation in line with Community law, which causes reform of the legal system of the country as a whole. The path to European integration involves the real protection and protection of fundamental human rights and freedoms, the creation of a rule of law, social and democratic state that will have a worthy place in the world community.

This process, among other things, involves a full-scale reform of Ukraine's legal system based on the principles and standards established at the pan-European level on the basis of modern democratic international law as a result of the activities of European regional international organizations. This is the reason for our country's accession to the European legal space, which is defined by the internal normative acts of Ukraine as a necessary condition for integration of Ukraine into Eurospace and other European structures.

Today, our country is actively seeking to create an extensive, reliable and effective system of interaction between national law enforcement and other competent authorities and officials with foreign counterparts in investigating crimes of an international nature. In this regard, it is especially urgent to find and implement new organizational and managerial approaches in the field of international cooperation of these entities, while taking into account all the most important standards, principles and norms developed by the world community in this field.

The experience of foreign law enforcement in this field is of great theoretical and practical importance. After all, foreign countries have gained considerable experience today in working together to solve crimes of an international nature and to counter international crime. 


\section{Prerequisites of the need for cooperation of Ukraine and the European Union in the law enforcement field}

This process, among other things, involves a full-scale reform of Ukraine's legal system based on the principles and standards established at the pan-European level on the basis of modern democratic international law as a result of the activities of European regional international organizations.

Today, our country is actively seeking to create an extensive, reliable and effective system of interaction between national law enforcement and other competent authorities and officials with foreign counterparts in investigating crimes of an international nature. In this regard, it is especially urgent to find and implement new organizational and managerial approaches in the field of international cooperation of these entities, while taking into account all the most important standards, principles and norms developed by the world community in this field. The experience of foreign law enforcement agencies in this field is of crucial theoretical and practical importance. After all, foreign countries have gained considerable experience today in working together to solve crimes of an international nature and to combat international crime.

It should be noted that various aspects of cooperation in different spheres of public life were investigated by: A. Aksenov, M. Anufriev, V. Tropin, V. Bolotova, M. Kamlyk, Y. Sveventseva, O. Bandurka, A. Gliev, D. Grebelsky, I. Gutkin, K. Yermakov, N. Yablokov, I. Gerasimov, A. Zagorny, L. Drapkin, I. Mozhayeva, V. Stepanov, O. Vinogradova, M. Pashkovsky, V. Grebenyuk, V. Malyarenko., S. Kravchuk, V. Maksimenko and others.

The theoretical basis of the study is the work of well-known scientists in the field of administrative law and government, organization of cooperation in the field of law enforcement, such as: Averyanov, O.F. Andriyko, I.V. Aristova, O.M. Bandura,

D.M. Bahrach, V.V. Belevtseva, Yu.P. Bityak, V.T. Bilous, I.L. Borodin, A.S. Vasilyev, Yu.A. Vedernikov, D. Witfield, O.V. Vodianikov, I.P. Golosnichenko, I.I. Gorynetsky, V.S. Guslavsky, E.V. Dodin, G.V. Druzenko, V.K. Running around, V.O. Overgrown, R.A. Kalyuzhnyi, Yu.M. Kapitsa, S.V. Kivalov, V.V. Kovalenko, Yu.M. Kozlov, T.O. Kolomoets, V.K. Kolpakov, A.T. Komzyuk, V.V. Kopiyka, O.P Korenev, A.M. Kuchuk, V.I. Kurilo, E.V. Kurinny, O.I. Lezhenin, V.A. Lipkan, O.V. Negodchenko, N.R. Nizhnik, D.M. Ovsyanko, V.I. Olefir, I.L. Oliynyk, O.I. Ostapenko, I.M. Pakhomov, E. Pashkovsky, V.P. Petkov, S.V. Petkov, V.V. Polovnikov, D.V. Priymachenko, T.O. Protsenko, O.P. Ryabchenko, L.A. Savchenko, V.M. Selivanov, V.F. Sirenko, O.F. Skakun, Yu.M. Starilov, V.V. Stashis, V.Ya. Tatsiy, O.D. Tikhomirov, M.M. Tishchenko, O.V. Tyurina, 
V.G. Fathutdinov, T.O. Cymbalist V.V. Tsvetkov, V.P. Chaban, D.V. Yagunov, M.K. Yakimchuk et al.

These and other lawyers have made a significant contribution to the development of this cooperation. However, a number of issues remain fragmented and require scientific study, and this fully applies to cooperation with foreign law enforcement and competent authorities, officials of foreign countries, international organizations

The purpose of the study is the legal foundations of Ukraine's EU integration process in the field of law enforcement ${ }^{1}$.

The establishment of a rule of law in Ukraine has an increasing prospect both in the light of the principles of the current Constitution and in the light of the implementation of the national course on European integration. Ukraine's European aspirations require the pursuit of appropriate policies and implementation and development on the national basis of the democratic norms and values inherent in the countries of the European Union ${ }^{2}$.

Since Ukraine has announced its intention to integrate into the European community, one way of achieving this is to harmonize Ukrainian and European law in general and the legal rules governing law enforcement, in particular. Achieving this goal is possible only when mastering the content of European law in this field, as well as some theoretical terms and concepts (European integration, standards of law enforcement agencies, etc.). One, and perhaps the main of the problems of this process is the haphazard approach to this problem ${ }^{3}$.

With the adoption of the strategy of integration of Ukraine into the European Union, the implementation of the Partnership and Cooperation Agreement into national legislation was initiated. In order to fulfill the main provisions of the strategy, the Cabinet of Ministers approved the concept of adaptation of the legislation of Ukraine to the legislation of the European Union. The President of Ukraine signed the Decree "On a Sustainable Development Strategy "Ukraine 2020", which aims at introducing European standards of living in Ukraine and entering Ukraine into the leading positions in the world.

Speaking for the signing of various treaties, international cooperation between states in the humanitarian field today is characterized by a

\footnotetext{
${ }^{1}$ Свропейський Союз: Консолідовані договори. Київ. Port-Royal, 1999. 207 с.

Зайчук О. В., Крупчан О. Д., Ковальський В. С та ін. Сучасна правова енциклопедія. НДІ приватного права і підприємства НАПрН України. НДІ інтелектуальної власності НПрН України. Київ. Юрінком Інтер. 2015. 408 с.

${ }^{2}$ Корельський В., Перевалова В. Теория государства и права: учебник для вузов Москва: НОРМА-ИНФА. 2002. 549 с.

${ }^{3}$ Korelsky V., Perevalova V. Theory of state and law: a textbook for universities Moscow: NORMA-INFA. 2002. 549 p.
} 
significant deepening of the cooperation between law enforcement, judicial and other competent authorities and officials in the fight against crime. The geographical boundaries of international cooperation are constantly expanding, its scope and methods and forms are being improved. As a rule, when it comes to international cooperation in the field of investigating crimes of an international nature, this refers to international legal assistance, which is implemented on the basis of international treaties.

Cases where such legal assistance is provided without the conclusion of the relevant contracts are rarely and mainly related to decision making in a particular case at the level of the central executive body.

\section{Ways for a complete cooperation of Ukraine and the European Union in the law enforcement}

Legal aid treaties ensure the fullest exercise of national jurisdiction and the avoidance of conflicts of jurisdiction - for this very purpose, States conclude them.

Most of these treaties are bilateral in nature, but in some cases, subject to certain integration relations, legal aid is resolved on the basis of multilateral agreements. Ukraine is most actively involved in the legal aid system established within the CIS and the Council of Europe. In the first case, the main legal instrument is the 1993 Convention on Legal Assistance in Civil, Family and Criminal Matters ${ }^{4}$.

Legal co-operation within the Council of Europe is governed by a number of instruments, such as the Convention on Mutual Assistance in Criminal Matters (1959), the Convention on Extradition of Offenders (1957), the Convention on the Repatriation of Minors (1970), and the Convention on Transfer. criminal proceedings (1972) Convention on Legal Assistance and Legal Relations in Civil, Family and Criminal Matters, Convention on the Transfer of Sentenced Persons (1983) and others.

The general principles and directions of cooperation of law enforcement authorities of the EU Member States are laid down in Section VI of the "Regulation on cooperation in the field of justice and home affairs" of the Treaty on European Union. In particular, Art. 29 emphasizes that, without prejudice to the powers of the European Communities, the Union aims to provide citizens with a high level of security in the area of freedom, security and justice through joint action by Member States in the fields of police and judicial cooperation in criminal matters, the prevention of racism and xenophobia.

\footnotetext{
${ }^{4}$ Конвенція про правову допомогу і правові відносини у цивільних, сімейних і кримінальних справах від 22.01.1993.URL. http://zakon3.rada.gov.ua/ laws /show/ 997_009
} 
For example, the UN Convention against Corruption of 31 October 2003 provides for law enforcement cooperation aimed at detecting, suspending, detecting, investigating and preventing criminal offenses against corruption, such as: search and seizure and freezing of property; the detection, freezing and tracking of proceeds of crime defined in this Convention or of property the value of which corresponds to the value of such proceeds; property, equipment and other means used or intended to be used in the commission of the offenses established by this Convention; asset seizure; protection of witnesses, experts and victims; protection of persons reporting information; obtaining testimony from individuals or witnesses; service of court documents; overview of objects and places; provision of information, material evidence and expert opinions; providing originals or certified copies of relevant documents and materials, including government, banking, financial, corporate or commercial documents; detection and tracking of proceeds from criminal activity, property, means of committing crimes or other objects for the purpose of proving, promoting the voluntary appearance of relevant persons at the request of a State Party; providing information on its own initiative; providing any other assistance which does not contravene the law of the requesting State Party ${ }^{5}$.

The Law of Ukraine "On Ratification of the Council of Europe Convention on Laundering, Search, Seizure and Confiscation of Proceeds from Crime and on the Financing of Terrorism" of 17 November 2010 aims at preventing and counteracting the laundering of proceeds of crime, the basis of which is the Council of Europe Convention on the laundering, search, seizure and confiscation of proceeds of crime of 16 May $2005^{6}$.

This International Treaty establishes that each Party shall take such measures as may be necessary to enable it to seize the instruments and means of crime and proceeds or property the value of which corresponds to such proceeds, and to seize property, and to take measures to block, arrest and forfeiture: property into which income has been converted or converted; property obtained from lawful sources, if it was wholly or partially raisednot more than the estimated value of such income; profits or other benefits derived from proceeds, from property into which proceeds from crime have been converted or converted, or from property to which proceeds from crime have been attracted, up to the estimated value of such proceeds, in the same way and how much and how much it applies to revenue.

\footnotetext{
5 Конвенція Організації Об'єднаних Націй проти корупції від 31 жовтня 2003 року. Закон України від 18.10.2006 р. № 251-V. Відомості Верховної Ради Украӥни. 2006. № 50. $496 \mathrm{c}$.

6 Конвенція про відмивання, пошук, арешт та конфіскацію доходів, одержаних злочинним шляхом від 08.11.1990 p. URL. http:/ /zakon. nau.ua/ doc/?uid =1014.171.0
} 
Thus, international cooperation of law enforcement agencies is realized through the implementation of measures enshrined in international legal acts, insofar as they do not contravene the current legislation; the actions of the engagement participants must be coherent and purposeful; the main purpose of such cooperation is the indirect protection of human rights and freedoms through the effective, timely, comprehensive, complete and true prosecution; must be carried out in accordance with the applicable principles of international cooperation in the fight against crime.

Thus, the Decree of the President of Ukraine of June 27, 1999 No. 151 approved the list of central executive authorities responsible for carrying out the tasks defined by the Strategy for the Integration of Ukraine into the European Union. Thus, according to the above list, the Ministry of Internal Affairs of Ukraine is also part of the system of central executive authorities responsible for cooperation with the EU.

Law enforcement agencies, as the largest representatives of the executive branch, in the course of fulfilling their responsibilities for establishing cooperation between Ukraine and the EU, become direct participants in administrative and legal relations, where they can interact with each other or with the subordinate bodies of the executive branch of industry, and with other public authorities, local authorities, enterprises, institutions, organizations or individuals.

We also believe that one of the main factors in uniting the efforts of law enforcement agencies to accomplish tasks in the context of European integration processes should be to coordinate the interaction of existing law enforcement agencies. After all, coordination of law enforcement activities is one of the main management functions that unites and organizes the efforts of law enforcement agencies to achieve the overall socially desired goal.

The main components of law enforcement coordination include the following forms: joint meetings of colleges, operational meetings, exchange of information, introduction and use of unified databases, mutual use of training opportunities, development and implementation of special operations, issuance of methodological recommendations and other organizational and administrative documents.

By their nature, coordination should be an independent means of organizing management and should be used to ensure the coordination of the functioning of autonomous units of different law enforcement agencies with a common purpose. It would be advisable to develop coordination procedures in connection with the dynamics of coordination development in the performance of tasks and functions of law enforcement authorities, which will further determine the priority actions and content of tactical operations in documenting and investigating crimes. 
In the current context, a fundamental step towards bringing Ukraine closer to the European Union and establishing a new level of cooperation with it in the priority spheres of public life should be the introduction of significant refinements in the policy of systemic transformations in Ukraine, a significant strengthening of the social orientation of the state, increasing the effectiveness of the authorities constitutional issues in such a way that in Ukraine there is a democratic balance between the legislative and executive branches of power, the achievement in society of mutual understanding and harmony, improve current parliamentary cooperation between Ukraine and the EU.

Ukraine, EU institutions and EU member states have established various forms of mutually beneficial cooperation in the information field, such as: constant exchange of information and necessary documentation of the legislation in the field of communication; analysis of divergences of Ukrainian and EU communications legislation; development of normative documents for implementation of activities in the field of joint production of information media, planning and implementation of long-term scientific and technical research programs in the field of new information technologies, development and implementation of information and data security means; exchange of experts in order to create an effective information society in Ukraine and, as a consequence, to build a unified European information society; defining the strategy of mechanisms for active participation of Ukraine in the development of a unified European information society; information support of bodies of interstate cooperation; providing expert and technical assistance to Ukraine on the part of the EU in building an information society; standardization and unification of interstate electronic document circulation to the basic relevant international standards, etc.

It is proposed to reform the law enforcement system, in particular the service of police officers, whose main purpose is to adjust the tasks and functions of the law enforcement system, to introduce new principles of service, new criteria for evaluating the work of law enforcement agencies to enhance the protection of human rights and freedoms, as well as the interests of the public unlawful encroachment. At the same time, the reform identified the direction of ensuring a transparent system of competitive selection of persons for positions, created a new system of certification of law enforcement personnel, changed approaches to training employees of these bodies, which provided a change in their attitude to perform their duties in the direction of their awareness of giving state-sponsored services to ensure, first and foremost, the safety of each person, his or her personal and property rights, public and state interests. 
It is proposed to ensure that the rule of law is as transparent and friendly to society as possible. An important area is a thorough decentralization and implementation of effective mechanisms of public control over law enforcement. The principle of legality should be a priority in the work of such bodies: the system of issuing and executing orders should be such that a police officer is guided by law and does not carry out clearly criminal orders. At the same time, in the process of implementing the strategy, the Ministry of Internal Affairs of Ukraine was reformed into a governing body within the system of central executive bodies.

The next problem is communication itself, as a number of EU member states simply ignore requests from other countries. Therefore, representatives of national law enforcement agencies with representatives of foreign cultures should be given considerable attention by addressing the negative effects of culture clashes on interpersonal communication and group interaction.

The findings of cross-cultural psychologists suggest that the presence of certain differences and differences in the self-concept of representatives of collectivist and individualistic cultures causes different degrees of expression of the phenomenon of fundamental attribution error. Attribution should be understood as the conclusions that people make about the cause of events and about their own and others' behavior. Therefore, an attribution error is an incorrect (erroneous) interpretation of the behavior of other entities in terms of their internal state ${ }^{7}$.

Thus, in accordance with the Law of Ukraine "On Amendments to Certain Legislative Acts of Ukraine in connection with the Ratification of the Second Additional Protocol to the European Convention on Mutual Assistance in Criminal Matters", Article 85-3 of the Code of Criminal Procedure was set out as follows: "In case the participants of investigative or other procedural action cannot appear at the inquest body, investigator, prosecutor or court at the place of trial, as well as the need to ensure the safety of the persons involved in criminal proceedings, or for other justified reasons, the investigative or procedural their involvement can be done by a conference call or a video conference. A conference call or video conference is held on the instructions of the investigating authority, investigator, prosecutor or court. Videoconferencing can be used during the interrogation of a witness, expert, suspect, accused and defendant, eye rate, presentation for identification, playback of the situation and circumstances of the event. Investigative actions during a video conference with the participation of the suspect, accused and defendant shall be conducted only with their written consent, as indicated in the protocol of the investigative action.

7 Стратегія сталого розвитку “Україна-2020". Затверджена Указом Президента України від 12 січня 2015 р. № 5. 
A conference call may be used when interviewing a witness or expert with their written consent. During the conference or video conference, audio or video is recorded. The body of the inquiry, the investigator, the prosecutor or the court being prosecuted and the executing authority shall draw up separate protocols to which a conference or videoconference is required, to which the appropriate audio or video recording is obligatory.

It is also worth noting Article 18, paragraph 18, of the United Nations Convention against Transnational Organized Crime, which states that, to the extent possible, it complies with the fundamental principles of domestic law, if any person is within the territory of a State Party and should be heard as a witness or expert by the judicial authorities of another State Party, the first State Party may, at the request of another State Party, authorize a hearing by communication if the personal presence of the respondent Noah persons on the territory of the requesting State Party is not possible or desirable.

States Parties may agree that the hearing shall be conducted by the judicial authority of the requesting State Party in the presence of representatives of the judicial authority of the requested State Party ${ }^{8}$.

However, in practice, the use of telephone and video conferencing in normal use is hindered by their dependence on complex technical infrastructure.

At present, the European Union is still at the stage of its territorial and political formation, so it is only natural that it should focus its efforts first on preventing urgent threats. Therefore, priority areas for cooperation with Ukraine in the field of security are the fight against organized crime, international terrorism, money laundering, drug trafficking and illegal migration. Recently, administrative reform in Ukraine has been closely linked to the implementation of constitutional reform, the content of which is reformatting the balance of higher power structures, ie the redistribution of powers and responsibilities between the President, the Government and Parliament, minimizing the threat of power, establishing transparent transparency. coalitions.

In our view, the implementation of constitutional reform has somewhat complicated and slowed down the administrative reform process, as both the President and the Government and Parliament will not be able, for some time, to develop an effective decision-making mechanism and identify new opportunities for executive and local government., which can destabilize the political situation in Ukraine and discredit Ukraine's image in the international arena.

${ }^{8}$ Афанасіаді Д.М. Адміністративно-правові засади правоохоронних органів та інших органів при розслідуванні міжнародних злочинів. автореф. на здобут канд. юр. наук. 12.00.07. Дніпропетровськ. 2012. 22 с. 
We believe that there are disputes between the President, the Government and the Parliament due to the fact that these public authorities were not quite ready for such changes. In addition, agreeing with the view of former Foreign Minister A. Zlenko, it should be noted that a certain imbalance among the higher structures of state power is caused by the imperfection of the constitutional changes themselves, by the presence of different interpretations of the Constitution, which in some way leads to disputes between the above mentioned entities. and undermines the principles of their effective functioning

Administrative reform is central because it is related to the need to streamline the system of central executive bodies, increase their efficiency, strengthen the leading role of ministries as the main subjects of development and implementation of state policy, reform the local government system through municipal reform.

As the issues of integration of Ukraine into the European community are highlighted, the establishment of cooperation between Ukraine and the EU member states, one of the ways of solving which is the achievement of European standards and values in the field of state administration (in particular, reforming the system of executive bodies and local selfgovernment through the creation of public administration), it is in this area of reform that we must focus our attention. In addition, it should be noted that the need to study the peculiarities of the creation and functioning of public administration in Ukraine is due to the widespread use of this concept in EU countries, as well as the need to establish a new level of cooperation between Ukraine and the EU in modern conditions ${ }^{9}$.

V. Melnyk stated that the analysis of police activity of individual countries of the world gives grounds to claim that in European countries police activity is community oriented, that is, to establish close links with the population. Therefore, in many countries, programs have been put in place for police interaction with the public, including "Stop the Offender", "Safe Housing Patrol", "Community Patrol", Neighborhood Assistance", "Combined Selective Patrol", "Precinct Police Offices, Department Stores offenses", "Rural Crime Prevention Unit by Radio Stations", "Bicycle Patrol", "Senior Precinct Concept" and others ${ }^{10}$.

However, unfortunately in Ukraine today, the public does not actively participate in the proper provision of the process of adaptation of the

\footnotetext{
9 Конвенция Организации Объединенных Наций против транснациональной организованной преступности. URL: http://www.un.org/ru/documents/decl_conv/ conventions/orgcrime.shtml

10 Про внесення змін до Конституції України: Закон України від 8 грудня 2004 року // Відомості Верховної Ради України. 2005. № 2. С. 44.
} 
administrative legislation of Ukraine to EU norms and standards. We believe that this situation is caused by the fact that no real and effective mechanisms for involving the public (eg relevant non-governmental organizations, independent think tanks) in the adaptation process have been created yet; their consciousness.

Taking into account that the administrative-territorial units of Ukraine have land and sea borders with neighboring states, the activation of border cooperation in the aspect of cooperation of certain regions is of particular importance for our country. Its dynamic development is largely determined by the peculiarities of the current stage of international relations. Direct links between the border regions have become widespread on the European continent, making the existence of Europe of the Regions a reality.

In addition, at the border of Ukraine and Russia there is a need to create an optimal network of checkpoints and maximum approximation of their infrastructure and functioning mechanism to the requirements of the EU, which will create favorable conditions for cross-border cooperation, use of Ukraine's transit potential, accelerate socio-economic development of border regions. The arrangement of the border infrastructure is one of the elements of the implementation of the strategic course of Ukraine before EU membership. The incompleteness of the contractual legal registration of the state border of Ukraine is a threat to the national interests and security of Ukraine

The development of the state border infrastructure in Ukraine implies the realization of short and long term tasks: the border should maximally promote the legal movement of persons, goods and vehicles and at the same time meet all modern requirements in order to securely protect national and economic security. Therefore, it is important to create the conditions for increasing the efficiency of the national network of international transport corridors, the formation of an integrated system of border protection in Ukraine and the maritime economic zone, the development of regulatory framework of border activity, further optimization of the structure of the State Border Service of Ukraine ${ }^{11}$.

The main problem of the system of institutional support of European integration of Ukraine remains the lack of effective coordination in this field and insufficient staffing of the process of European integration (especially in the sphere of legislative approximation), since the established system of executive authorities has shown its inefficiency and requires significant improvement. Therefore, it is necessary to decide on the creation of a single

${ }^{11}$ Мосенцева Т. Конституційна реформа: внутрішні та зовнішні чинники (інтерв’ю 3 екс-міністром закордонним справ А. Зленком) // День. № 36.28 лютого 2007 року. 
coordinating body within the system of bodies of the executive power of Ukraine, which would formulate a strategy of relations between Ukraine and the EU and would be responsible for its effective implementation.

It is also advisable to analyze and review the functional responsibilities and activities of the structural units of central executive bodies responsible for implementing European integration policies. The competence of the Parliamentary Committee on European Integration and the Main Legal Department of the Verkhovna Rada in the area of legislative approximation is needed in order to increase Parliament's ability to exercise proper control over these activities. In addition, it is necessary to anticipate and consolidate at the legislative level the mechanism of accountability of public authorities of Ukraine (officials) in the field of establishing effective cooperation between Ukraine and the EU in priority areas for the improper execution by a particular public authority of its powers (or their excess) in the sphere of cooperation. Therefore, the improvement of legislation in the field of cooperation between law enforcement agencies of Ukraine and the EU should be achieved through the consolidation at the legislative level of the strategy "community rolicing", numerous changes and additions to the by-laws, the establishment of closer cooperation between police and urban.

Thus, in view of all the above, we believe that the need to reform public administration in Ukraine by bringing the activities of executive bodies and local self-government in line with the standards and principles of activity of public administrations in European countries by creating an effective and relatively stable system of executive bodies, the division of powers between executive power on the ground and local self-government bodies, ensuring the implementation of delegated powers, introduction of a rational and transparent procedure for public policy-making with the involvement of the public, development and implementation of effective legal mechanisms for protecting citizens in relations with public administration bodies is one of the prerequisites for Ukraine to become a full member of the EU, to which all state bodies should be directed. authorities in Ukraine.

Of particular importance is the large-scale outreach work, including the development and implementation of a national program to inform the public about the situation in the EU, the problems and gains of Ukraine on the path of European integration. The media also need orientation on coverage of the development of relations between Ukraine and the EU, a broad and comprehensive explanation of the importance of Ukraine's European choice, ensuring impartial perception of European integration by citizens, regular information on political, economic and social processes taking place in EU countries. achievements through the joint resolution of individual issues. 
The need to improve the legal framework for the organization and operation of law enforcement agencies and to reform the existing system on this basis is conditioned by the course of building a social, legal and democratic state and civil society and Ukraine's acceptance of a number of international legal commitments in the field of human and citizen's rights. The proper functioning and development of the international law enforcement sector is largely determined by the quality level of activity of the entities.

In the context of social transformation of modern Ukraine, the question of forming a fully-fledged European-type rule of law is particularly acute. It should be noted that the nation as a whole and its legitimate authorities and public administration have determined the historical perspective of the development of Ukrainian society, which has been embodied in an officially proclaimed course for integration into Europe and its structures, the implementation of which provides for bringing the norms and standards of our internal life. society in accordance with the norms and standards of Europe.

A special issue for Ukraine now is to preserve its territorial integrity. The control and coordination of cooperation at the EU external border is carried out by the European Agency for the Management of Operational Cooperation at the EU's External Borders, FRONTEX. On June 11, 2007 in Luxembourg, during the meeting of Ministers of Justice and Home Affairs in Ukraine-EU Troika format, the Working Agreement on Establishing Operational Cooperation between the STS of Ukraine and FRONTEX was signed(European Agency for the Management of Operational Cooperation at the External Borders of the Member States of the European Union, pursuant to Council Regulation (EC) No 2007/2004 of 26.10.2004, contributes to enhancing border security by ensuring the coordination of the activities of Member States in the implementation of Community actions concerning the management of external borders).

This arrangement obliges the Border Agency of Ukraine to the following activities: counteracting uncontrolled migration and other illegal activities at the border, enhancing border security between EU Member States and Ukraine, developing good relations and mutual trust between border authorities between border agencies at the border EU and Ukraine. An important area of cooperation between Ukraine and the EU in the area of border and customs issues is the activity of the European Commission Mission for Border Assistance to Ukraine and the Republic of Moldova (hereinafter - EUBAM Mission).

On October 7, 2005, a Memorandum of Understanding was signed between the Government of Ukraine, the Government of the Republic of 
Moldova and the European Commission on a European Border Assistance Mission to Ukraine and the Republic of Moldova (EUBAM), which created the legal framework for practical cooperation between Ukraine and the EU. on customs and border issues ${ }^{12}$.

Based on the Decree of the Cabinet of Ministers of Ukraine No. 57-r of 13.04.2007 "On approval of the draft Agreement (in the form of an exchange of notes) between the Government of Ukraine, the Government of the Republic of Moldova and the European Commission on the extension of the mandate of the European Commission Border Assistance Mission in Ukraine and the Republic of Moldova "has been extended the mission until December 1, 2009. This Mission is an advisory and technical body.

The Mission's practice includes conducting joint operations with law enforcement, customs and border services of Ukraine and the Republic of Moldova. The purpose of the operations is to improve cooperation between the border and customs authorities of the two countries, to increase the effectiveness of operational interaction between border, customs and law enforcement services, to strengthen the fight against negative phenomena at the border.

Coordination meetings are held each month with the participation of representatives of foreign policy agencies, border and customs services, ministries of internal affairs, justice and security services of Ukraine and the Republic of Moldova. The EUBAM Mission Advisory Board meets quarterly on a regular basis ${ }^{13}$.

The Mission's main tasks are: to work with Ukraine and Moldova to harmonize border management standards and procedures with those in force in the EU; promote the professionalism of Ukrainian and Moldovan customs and border services at the operational level; develop risk analysis systems; to improve cooperation and complementarity between border and customs services and other law enforcement agencies; support cross-border cooperation.

The Mission provides field training and advice to Ukrainian and Moldovan officials to enhance the capacity of their services to carry out effective border and customs control and border surveillance.

12 Білозерська Т.О. Адміністративно-правові засади співробіництва України та Європейського Союзу у сучасних умовах : автореф. на здобут. канд. юр наук. 12.00.07. 2009. 22 c.

${ }^{13}$ Мельник В.І. Впровадження "community policing” у діяльність дільничних офіцерів поліції під час охорони публічного порядку в сільській місцевості. URL: http://dspace.onua.edu.ua/bitstream /handle/11300/9648/Мельник\%20B.I.\%20\%20Впровадження\% 20community\%20policing.pdf. 
Yes, HUREMAS (Human Resources Management) is a project implemented by the International Organization for Migration with the support of partners from EU Member States and funded by the European Commission and the US Department of State. The project partners work closely with the STS of Ukraine to reform and improve the procedures for recruiting, training and career advancement of STS personnel, as well as providing the necessary technical assistance and equipment to the Service, improving the legal framework in the field of state border protection, in order to strengthen Ukraine's ability to solve problems. border security. This project is being implemented to support the efforts of the Government of Ukraine to accede to EU and Schengen standards, which involves the transformation of the MRF into a civil law enforcement structure ${ }^{14}$.

The Ukrainian Border Agency works under the conditions of constant control by the EU.

Ukraine also cooperates with European countries with no borders, such as France. Thus, on December 12, 2005 the Protocol on Cooperation between the Administration of the State Border Guard Service of Ukraine and the Central Border Police Office of the French Republic was signed. The Parties agreed to provide assistance in order to effectively combat illegal migration by exchanging information in the following areas: 1) flows of illegal migration at their national borders; 2) nationality of illegal migrants; 3) channels of illegal migration; 4) the methods and methods used to organize the channels of illegal migration; 5) ways of forgery of documents and their acquisition; 6) new regulatory acts on border issues and combating illegal migration; 7) introduction of modern technologies of state border protection, counteraction to illegal migration and falsification of documents; 8) training of staff and implementation of cooperation by mutual agreement of the Parties.

Border cooperation of Ukraine with the neighboring countries and the EU provides not only the regulation of the issues of effective use of borders, but also the functioning of the European Border Agency with the powers that will allow the effective exercise of the existing powers to this body. In most European countries, the issue of law enforcement activities in the border services has been resolved through the entry into the Ministry of the Interior of these services and the full or limited extension of the rights and powers of national police to their staff. Improving the effectiveness of border protection can be achieved by accelerating the process of demarcation of the state border.

14 Катеринчук І.П. Правові та організаційні засади співробітництва України та Європейського Союзу в правоохоронній сфері. Автореф.на здобут. канд. юр. наук. 12.00.07. Ірпінь. 2009. 22 с. 
One of the priorities for cooperation, which needs to be addressed as a matter of priority, is the EU's Joint Strategy for Ukraine identifying justice and home affairs, in particular ensuring the security of Ukraine's borders and deterring illegal migration through Ukraine to the $\mathrm{EU}^{15}$.

The process of European integration is a powerful impetus for institutional change in the field of migration policy. For candidate countries, this is one of the EU's requirements for membership. Given the above, we can conclude that a major step towards EU-Ukraine cooperation should be to concentrate efforts on gaining EU member status. The European legal area is the result of the interaction of the legal systems of European states with regional norms of international law and norms created through the legal activities of European organizations (EU law, Council of Europe, OSCE / OSCE). After all, international cooperation of law enforcement agencies is implemented through the implementation of measures enshrined in international legal acts, insofar as they do not contravene the current legislation; the actions of the engagement participants must be coherent and purposeful; the main purpose of such cooperation is the indirect protection of human rights and freedoms through the effective, timely, comprehensive, complete and true prosecution; must be carried out in accordance with the applicable principles of international cooperation in the fight against crime.

And the need to reform public administration in Ukraine by aligning the activities of the executive and local self-government bodies with the standards and principles of the public administrations of European countries by creating an effective and relatively stable system of executive bodies, delimiting the powers between local and local governments, ensuring the fulfillment of delegated powers, the introduction of a rational and transparent public policy-making procedure, the development and implementation of effective legal mechanisms for protecting citizens in relations with public administration bodies is one of the prerequisites for Ukraine to become a fully-fledged EU member state. directed efforts of all public authorities in Ukraine.

And there is an important role in this process of conducting large-scale outreach work, in particular the development and implementation of a national program to inform the public about the situation in the EU, the problems and gains of Ukraine on the path of European integration. The media also need orientation on coverage of the development of relations

15 Меморандум про взаєморозуміння між Урядом України, Урядом Республіки Молдова та Європейською Комісією щодо місії Європейської Комісії з надання допомоги в питаннях кордону в Україні та Республіці Молдова від 07.10.2005 р. ОВУ. 2006. № 16. Ст. 1248. 
between Ukraine and the EU, a broad and comprehensive explanation of the importance of Ukraine's European choice, ensuring impartial perception of European integration by citizens, regular information on political, economic and social processes taking place in EU countries. achievements through the joint resolution of individual issues ${ }^{16}$.

\section{CONCLUSIONS}

We believe that the need to reform public administration in Ukraine by aligning the activities of executive bodies and local self-government with the standards and principles of public administrations in European countries by creating an effective and relatively stable system of executive bodies, and the division of powers between local and regional authorities local selfgovernment, ensuring the implementation of delegated powers, introduction of a rational and transparent procedure for public policy-making with the involvement of the public, development and implementation of effective legal mechanisms for protecting citizens in relations with public administration bodies is one of the prerequisites for Ukraine to become a full member of the EU, to which all state bodies should be directed. authorities in Ukraine.

Of particular importance is the large-scale outreach work, including the development and implementation of a national program to inform the public about the situation in the EU, the problems and gains of Ukraine on the path of European integration. The media also need orientation on coverage of the development of relations between Ukraine and the EU, a broad and comprehensive explanation of the importance of Ukraine's European choice, ensuring impartial perception of European integration by citizens, regular information on political, economic and social processes taking place in EU countries. achievements through the joint resolution of individual issues.

In order to improve cooperation between Ukraine and the EU, a number of laws are needed to improve migration policy, counter-terrorism and crime.

\section{SUMMARY}

In connection with Ukraine's determination of a strategic goal integration into the European Union, including membership in this international association - it is an important task to bring national legislation in line with Community law, which causes reform of the legal system of the country as a whole. The path to European integration involves the real

${ }^{16}$ Спільна стратегія Свропейського Союзу щодо України, схвалена Свропейською Радою від 11.12.1999 p. URL: http://zakon1.rada.gov.ua/cgi-bin/laws/main.cgi?nreg=994_492 
protection and protection of fundamental human rights and freedoms, the creation of a rule of law, social and democratic state that will have a worthy place in the world community. The purpose of the article is to study the theoretical and legal foundations of Ukraine's EU integration process in the law enforcement field. Because of the experience of foreign experience, Ukraine is simply obliged to use it. Because today, foreign countries have accumulated considerable experience in joint activities to solve crimes of an international nature and combating international crime. Ukraine has announced its intention to integrate into the European Community, so it is quite relevant to adapt the national legislation to the European Union. The National Police of Ukraine is now in the process of global reform. The successful reform of law enforcement agencies depends on the completion of the reform of almost all strategic areas in Ukraine. Completing the reforms is a global task for every Ukrainian on the path to a better life.

\section{REFERENCES}

1. Свропейський Союз: Консолідовані договори. Київ. Port-Royal, 1999. $207 \mathrm{c}$.

2. Зайчук О. В., Крупчан О. Д., Ковальський В. С та ін. Сучасна правова енциклопедія. НДІ приватного права і підприємства НАПрН України. НДІ інтелектуальної власності НПрН України. Київ. Юрінком Iнтер. 2015. $408 \mathrm{c.}$

3. Корельський В., Перевалова В. Теория государства и права: учебник для вузов Москва: НОРМА-ИНФА. 2002. 549 с.

4. Конвенція про правову допомогу i правові відносини у цивільних, сімейних і кримінальних справах від 22.01.1993. URL: http://zakon3.rada.gov.ua/ laws /show/ 997_009 (дата звернення 15.11.2019)

5. Конвенція Організації Об'єднаних Націй проти корупції від 31 жовтня 2003 року. Закон України від 18.10.2006 p. № 251-V. Відомості Верховної Ради України. 2006. № 50.496 с.

6. Конвенція про відмивання, пошук, арешт та конфіскацію доходів, одержаних злочинним шляхом від 08.11.1990 p. URL: http://zakon.nau.ua/doc/?uid=1014.171.0 (дата звернення 15.11.2019)

7. Стратегія сталого розвитку “Україна-2020". Затверджена Указом Президента України від 12 січня 2015 р. № 5.

8. Афанасіаді Д. М. Адміністративно-правові засади правоохоронних органів та інших органів при розслідуванні міжнародних злочинів. автореф.на здобут канд. юр. наук. 12.00.07. Дніпропетровськ. 2012. $22 \mathrm{c}$. 
9. Конвенция Организации Объединенных Наций против транснациональной организованной преступности. URL: http://www.un.org/ $\mathrm{ru} /$ documents/decl_conv/conventions/orgcrime.shtml (дата звернення 15.11.2019)

10. Про внесення змін до Конституції України : Закон України від 8 грудня 2004 року // Відомості Верховної Ради України. 2005. № 2. C. 44.

11. Мосенцева Т. Конституційна реформа: внутрішні та зовнішні чинники (інтерв'ю з екс-міністром закордонним справ А. Зленком) // День. № 36. 28 лютого 2007 року.

12. Білозерська Т. О. Адміністративно-правові засади співробітництва України та Свропейського Союзу у сучасних умовах. автореф. на здобут. канд. юр. наук.12.00.07.2009. 22 с.

13. Мельник В.I. Впровадження "community policing” у діяльність дільничних офіцерів поліції під час охорони публічного порядку в сільській місцевості. URL: http://dspace.onua.edu.ua/bitstream/handle/ 11300/9648/Мельник\%20B.I.\%20\%20Впровадження\%20community\% 20policing.pdf (дата звернення 15.11.2019)

14. Катеринчук І.П. Правові та організаційні засади співробітництва України та Свропейського Союзу в правоохоронній сфері. Автореф. на здобут. канд. юр. наук. 12.00.07. Ірпінь. 2009. 22 с.

15. Меморандум про взаєморозуміння між Урядом України, Урядом Республіки Молдова та Європейською Комісією щодо місії Європейської Комісії з надання допомоги в питаннях кордону в Україні та Республіці Молдова від 07.10.2005 р. ОВУ. 2006. № 16. Ст. 1248.

16. Щодо місії ЄК з надання допомоги у питаннях кордону України та Республіці Молдова. Офіційний веб-сайт Міністерства закордонних справ України. URL: http://www.mfa.gov.ua/mfa/en/publication/ content/19993.htm (дата звернення 15.11.2019)

17. Спільна стратегія Свропейського Союзу щодо України, схвалена Європейською Радою від 11.12.1999 p. URL: http://zakon1.rada.gov.ua/ cgi-bin/ laws/ main. cgi? nreg=994_492 (дата звернення 15.11.2019).

\section{Information about the author:} Bondar V. V.,

Head of Department of Administrative Law and Administrative Process, Kherson Faculty of the Odessa State University of Internal Affairs 1, Fonvizina str., Kherson, 73000, Ukraine 